\title{
EM Busca de UMa FundamentaÇáo PARA A MEMÉTICA
}

\author{
Gustavo Leal-Toledo ${ }^{1}$
}

RESUMO: O conceito de memes surgiu em 1976 com Richard Dawkins, como um análogo cultural dos genes. Deveria ser possível estudar a cultura através do processo de evolução por seleção natural de memes, ou seja, de comportamentos, ideias e conceitos. O filósofo Daniel Dennett utilizou tal conceito como central em sua teoria da consciência e pela primeira vez divulgou para o grande público a possibilidade de uma ciência dos memes chamada "memética". A pesquisadora Susan Blackmore (1999) foi quem mais se aproximou de uma defesa completa de tal teoria. No entanto, a memética sofreu pesadas críticas e ainda não se constituiu como uma ciência, com métodos e uma base empírica bem definida.

PALAVRAS-CHAVE: Memes. Memética. Darwinismo Universal. Richard Dawkins. Daniel Dennett.

O presente trabalho visa não apenas a apresentar de forma simples a memética, a partir de seus fundamentos conceituais, mas também levantar alguns de seus problemas, em especial problemas conceituais que impedem o desenvolvimento empírico da mesma. Com base em uma crítica de como a memética foi exposta por uma de suas principais defensoras, Susan Blackmore, será feita uma nova aproximação à ciência dos memes, onde esta teria o papel de "cola conceitual" entre as diversas áreas que estudam a cultura e seu desenvolvimento. Essa nova aproximação daria o fundamento empírico à memética, que falta nas análises de Blackmore, permitindo assim que ela se desenvolva propriamente.

Para entender o que é a memética, é preciso compreender antes o que é o Darwinismo Universal, mas, para entender este, é preciso compreender o darwinismo. No entanto, explicar o darwinismo fugiria completamente

\footnotetext{
${ }^{1}$ Docente do DTECH da Universidade Federal de São João del-Rei. Agradece o apoio do CNPq e demais entidades, através do projeto aprovado pelo edital MCTI /CNPq /MEC/CAPES 07/11.
} 
do escopo deste texto. Mas há uma maneira mais direta de explicá-lo, que já pode ser imediatamente utilizada para explicitar o darwinismo universal: podemos tratar o darwinismo como um processo abstrato, destacando só as características essenciais que tal processo exige.

Dawkins coloca, no início de todo o processo de evolução, o chamado "replicador", sem especificar qual é esse replicador. Para haver um processo de evolução por seleção natural, é necessário um replicador com hereditariedade. Aqui surge o foco do chamado "Darwinismo Universal": o importante do gene não é que ele é uma cadeia de DNA, porém, que ele é um replicador, ou seja, algo que faz cópias de si mesmo. Desse modo, se ele fosse feito de outra substância, a qual também pudesse se replicar, ele também seria alvo da seleção natural e, por conseguinte, da evolução. É nesse sentido que o ultradarwinismo2 quer ultrapassar as barreiras do darwinismo.

Para o darwinismo universal, o darwinismo não se restringe a um estudo da biologia do nosso planeta. Nas palavras de Pinker, o darwinismo universal defende que

[a] seleção natural não é só a melhor teoria da evolução da vida na terra, mas quase com certeza é a melhor teoria da evoluçáo da vida em qualquer lugar do universo (PINKER, 2006, p. 132).

Onde houver um replicador capaz de passar suas características para seus descendentes e houver um suprimento finito de "nutrientes" necessários para a replicação, ocorrerá a seleção natural e, por consequência, a evolução. Isso quer dizer que a evolução não depende do substrato biológico aqui da Terra, de sorte que ela pode se dar em outros planetas, com outros substratos. Como ressalta Dennett "[...] as idéias de Darwin sobre os poderes da seleção natural também podem ser retiradas de sua base biológica" (DENNETT, 1998, p. 60). Com isso, ele não está querendo dizer que tais ideias podem ser aplicadas só a outros planetas, mas aplicadas a qualquer ambiente onde existirem outros replicadores. Nas palavras de Dawkins, “[...] o darwinismo é uma teoria grande demais para ser confinada ao contexto limitado do gene" (DAWKINS, 2001, p. 213).

\footnotetext{
${ }^{2}$ O termo "ultradarwinismo" tem uma conotação pejorativa, dada por Stephen Jay Gould; no entanto, essa conotação será ignorada no que se segue, e tal termo será tratado como equivalente ao darwinismo universal.
} 
Mesmo dentre aqueles que não defendem claramente que a evolução é um processo algorítmico, é comum encontrar o que eles chamam de um "resumo abstrato" da evolução, pelo qual ela é "[...] abstratamente compreendida como um argumento lógico, que leva das premissas a uma conclusão" (RIDLEY, 2006, p.104). Ridley enumera quatro condiçôes fundamentais para a existência da seleção natural: reprodução, hereditariedade, variação, variação da aptidão (algumas variaçóes serão melhores do que outras). Até Darwin fez o seu pequeno resumo abstrato da seleção natural:

Como nascem muito mais indivíduos de cada espécie e que não conseguem subsistir; como, por conseqüência, a luta pela sobrevivência se renova a cada instante, segue-se que todo o ser que varia, ainda que pouco, de maneira a tornar-se-lhe aproveitável tal variaçáo, tem maior probabilidade de sobreviver, este ser torna-se também objeto de seleçáo natural. Em virtude do princípio poderoso da hereditariedade, toda variedade, agente da seleção, tenderá a propagar sua nova forma modificada. (DARWIN, 2004, p. 19-20).

Embora seja fácil ler esse trecho pensando especificamente em seres vivos evoluindo no planeta Terra - e provavelmente era nisso que Darwin pensava -, é possível notar que ele não faz referências específicas e que poderia estar tratando de qualquer outra coisa capaz de se reproduzir e com aptidáo variável. Isso fica claro na forma de argumento lógico que Darwin escolheu para esse trecho, ao usar as palavras "como... como... segue-se..." Essa separaçấo da evolução da sua base biológica é muito comum e inúmeros outros exemplos poderiam ser dados (cf. MAYNARD-SMITH, 1993, p. 43-44; DAWKINS, 2001, p. 193-194). Todos eles são muito parecidos e em última instância se resumem a isto:

Se uma populaçáo variada de entidades produz descendentes semelhantes a si, e se essas entidades diferem em adaptatividade, a seleçáo deverá gerar alterações evolutivas nessa população independentemente do tipo de entidade em questão. (STERELNY; GRIFFITHS, 1999, p. 41, tradução minha).

Curiosamente, é comum que esses resumos abstratos se esqueçam de dois tópicos importantes: é preciso que exista uma falta de recursos para a reprodução. Se a quantidade de recursos for infinita, até um indivíduo que não esteja bem adaptado poderá sobreviver. Também é necessário tempo para que todo esse processo se realize. Este último parece ser óbvio: ninguém defende que a evolução se dê instantaneamente. No entanto, o tempo transcorrido 
pode ser menor do que o exigido pela evolução e, nesse caso, não poderá ter sido ela a causadora das mudanças.

Vemos, portanto, que existem algumas condições necessárias em todo processo de evolução por seleção natural, a saber: reprodução com herdabilidade ${ }^{3}$, variação intraespecífica, possibilidade do surgimento de novas mutaçóes, aptidão diferencial, falta de recurso para a reprodução, tempo para o processo ocorrer. $\mathrm{Na}$ presença dessas condiçóes, a seleção natural acontece e, consequentemente, a evolução.

A despeito das críticas contra esse tipo de abstração do processo evolutivo, a força de tal processo compreendido de maneira abstrata é utilizada hoje para explicar inúmeros outros processos e teorias, dentre os quais a própria memética. Mas, mesmo ainda dentro da área da biologia, ele é usado para explicar outros processos como, por exemplo, o sistema imune. Este parece funcionar de uma maneira análoga à evolução por seleção natural. Sabemos que o que mais importa na relação de um anticorpo e seu antígeno é a sua forma tridimensional; seguindo o termo técnico, devemos dizer que o que importa são suas propriedades estereoespecíficas, "[...] isto é, sua capacidade de 'reconhecer' outras moléculas [...] segundo a sua forma, a qual é determinada por sua estrutura molecular” (MONOD, 2006, p. 58). A relação entre o antígeno e o anticorpo é semelhante à relação entre uma chave e uma fechadura. No entanto, a forma original do anticorpo náo se deve a forma do antígeno: os anticorpos são produzidos aleatoriamente em variadas formas, de sorte que o antígeno serve como seletor dessas formas. As formas que encontram seu antígeno se multiplicam e tornam-se mais comuns, e as que não encontram se tornam mais raras (MONOD, 2006, p. 125-126).

Um outro processo em que a estrutura abstrata da seleção natural desempenha um papel diz respeito à origem da vida conforme exposta por Cairns-Smith. Segundo o autor, os cristais, como os encontrados na argila e no barro, são um conjunto ordenado de átomos que tendem a se aglomerar nessa forma ordenada. Por mais ordenado que eles sejam, podem existir pequenas falhas na sua ordenação. O que é interessante é que eles podem crescer. Fazem isso agregando novas camadas da mesma substância, seguindo sempre a mesma ordenação (DAWKINS, 2001, p. 224).

\footnotetext{
${ }^{3}$ Năo basta o caractere ser herdável, ele precisa ter alguma herdabilidade, ou seja, precisa criar algum diferencial fenotípico na população, a fim de que possa ser selecionado ou não.
} 
De certa maneira bastante simples, o cristal se reproduz e até apresenta hereditariedade, pois, se o cristal original tiver alguma falha, os novos cristais que surgirão a partir dele tenderão a ter essa mesma falha. É possível que algumas falhas tornem os cristais mais capazes de se reproduzir, podendo torná-los mais leves ou mais rápidos em sua reprodução etc. Teríamos, então, uma espécie de seleção natural dos cristais. Cairns-Smith une essa interessante perspectiva com uma relação química conhecida entre os cristais e certas moléculas orgânicas, para propor uma explicação plausível para o surgimento da vida orgânica. Todavia, os detalhes da teoria de Cairns-Smith não nos interessam aqui; o que é importante é que, nesse caso, os cristais é que são os primeiros replicadores, o DNA e o RNA é que teriam se originado depois e por intermédio deles. Sendo replicadores, os cristais poderiam sofrer um processo de seleção natural, é óbvio que extremamente simples, pois a estrutura dos cristais é muito organizada e infinitamente repetitiva. Além disso, a sua quantidade de informaçáo é muito inferior à do mais simples ser vivo, porém, esta seria só uma separação quantitativa (MONOD, 2006, p. 31).

Desse modo, o cerne do darwinismo universal é a afirmação de que, quando os recursos são escassos, aqueles indivíduos de uma população variável que forem mais aptos tenderão a ter mais descendentes e, como suas aptidóes são herdáveis, sua prole também será mais apta. Tal prole poderá ter novas mutaçóes que a tornem ainda mais apta, criando, assim, um processo de acumulação de mutaçôes que se convencionou chamar de evolução por seleção natural.

Uma vez percebido o que é o darwinismo universal, podemos compreender o que é a memética simplesmente afirmando que ela é o algoritmo da evoluçáo por seleçáo natural aplicada diretamente à cultura. A única questáo pendente seria, na verdade, saber se esse substrato tem todas as propriedades necessárias para implementar a evolução darwinista mencionadas anteriormente.

Foi justamente para deixar mais intuitiva a ideia de que a evolução independe do substrato que Dawkins cunhou, no último capítulo de seu livro O Gene Egoista, em 1976, o conceito de meme:

Precisamos de um nome para o novo replicador, um substantivo que transmita a idéia de uma unidade de transmissão cultural, ou uma unidade de imitaçâo. "Mimeme" provém de uma raiz grega adequada, mas quero um monossílabo que soe um pouco como "gene". Espero que meus amigos helenistas me perdoem se eu abreviar mimeme para meme. Se servir como 
consolo, pode-se, alternativamente, pensar que a palavra está relacionada com "memória", ou à palavra francesa même. (DAWKINS, 2001, p. 214)

Um meme pode ser concebido como uma unidade de cultura, um comportamento ou uma ideia que pode ser passada de pessoa para pessoa. Os exemplos de memes são inúmeros e os mais comumente citados são: a moda no vestuário e na alimentação, cerimônias e costumes, arte e arquitetura, engenharia e tecnologia, melodias, músicas, ideias, slogans, maneiras de construir arcos, o alfabeto, a linguagem, queimar a bandeira americana, a religião, o xadrez, o nazismo, a pornografia, os direitos humanos, o desconstrucionismo etc. Toda a cultura, todos os comportamentos sociais, todas as ideias e teorias, todo comportamento náo geneticamente determinado, tudo que uma pessoa é capaz de imitar ou aprender com outra pessoa é um meme.

A definição mais usada de memes foi dada por Susan Blackmore: “[...] memes são instruçóes para realizar comportamentos, armazenadas no cérebro (ou em outros objetos) e passadas adiante por imitação" (BLACKMORE, 1999, p. 17). Vemos já nesse ponto a referência à questão: os memes estão só em cérebros ou podem ser encontrados em outros substratos também como livros, CDS, fitas etc.? Tal questáo não será abordada aqui ${ }^{4}$. Além disso, Blackmore trata de memes como "instruçôes". Desse modo, ela habilmente foge de uma definição comum, empregada por Dawkins e Dennett, de memes como informação. É preferível utilizar essa definição, pois o conceito de informação não está bem definido nem mesmo na biologia, como muito bem observou Maynard-Smith (1993, p. 79).

Em uma primeira simplificação, podemos pensar nos memes como "padróes de comportamento": uma pessoa aprende a dançar imitando certo padrão de comportamento. Esse padrão pode ser bem adaptado ou não a essa pessoa. Será, por exemplo, mais bem adaptado se ela tiver um bom desempenho físico, um bom ouvido para seguir o ritmo da música, uma boa estrutura cerebral capaz de traduzir esse ritmo em movimentos do corpo, uma boa memória corporal, um gosto pelo tipo de música que está dançando, uma vida social que a leve a lugares onde se pode dançar etc. Tudo isso é o "ambiente" no qual esse meme vai se inserir. Se esse for o caso, ele estará bem adaptado a tal ambiente e poderá, dessa forma, ser passado para outras

4 Blackmore também levanta a questão de se memes são passados só por "imitação no sentido estrito" ou também por outras formas de aprendizado social. Tal aspecto tem relação direta com o problema de quais animais podem ter memes. Nenhuma dessas questôes será tratada aqui. 
pessoas, o que significa somente que essa pessoa tenderá a influenciar outras pessoas a dançar, seja através de incentivo verbal, seja dançando com elas, seja ensinando-as a dançar, ou mesmo somente sendo observada e admirada. Fica evidente que a memética deve, então, estudar também o substrato neural responsável pela imitação e pelo aprendizado social, estudo este que pode se beneficiar muito da recém-descoberta dos neurônios-espelho (RIZZOLATTI; SINIGAGLIA, 2008).

No entanto, não devemos pensar em memes só como cópias diretas de comportamentos. Em seu livro O Rio que saía do Éden (1996), Dawkins nos fornece uma análise muito interessante feita com a propagação de correntes de cartas. Ele alude à "carta de São Judas", a qual circulou o mundo em várias versôes, sendo já conhecida pelos registros oficiais do correio americano que relatam ser ela de uma época anterior a tais registros e exibir surtos epidêmicos recorrentes. Dawkins faz uma análise de tal carta, mostrando que podem ser encontradas mutaçôes que a tornam mais provável de ser passada, aumentando, desse modo, a sua frequência. Afirmações completamente implausíveis, por exemplo, tendem a mudar para afirmaçóes mais plausíveis e que apelam não diretamente para o medo, mas para o bom senso. Algo do tipo "talvez nada aconteça com você, mas não é melhor prevenir do que remediar?” é muito mais eficaz em se reproduzir do que "se você não mandar esta carta para sete pessoas em uma quarta-feira você morrerá na quinta”. Modificaçóes como estas vão gradualmente tornando a carta cada vez mais eficaz e, por isso, Dawkins pode dizer que "[...] como no caso das correntes de cartas, o sucesso entre os replicadores químicos é simplesmente sinônimo de freqüência de circulação" (DAWKINS, 1996, p. 130).

Muitos outros exemplos poderiam ser dados. Assim, existe um número limitado de livros impressos por ano. Um meme será impresso em um livro, se ele conseguir vencer os outros memes que querem ser impressos. O que determinará o vencedor é a adaptabilidade do meme ao ambiente externo. Dessa maneira, se uma editora costuma publicar livros de literatura, dificilmente publicará livros de filosofia. Os memes da filosofia não estão adaptados ao ambiente da literatura, do mesmo modo que uma banda de chorinho dificilmente vai gravar um CD de Hard Core etc. Todavia, mutaçóes podem ocorrer: os livros de filosofia podem ficar cada vez mais parecidos com livros de literatura. Se isso acontecer, eles poderão ser impressos pelas editoras de literatura e terão, assim, um maior sucesso replicativo. É esperado, portanto, que eles se tornem cada vez mais comuns devido ao seu sucesso adaptativo. 
É uma questão em aberto se, nesse caso citado, o ambiente dos memes é o próprio ambiente da literatura, como as gráficas, os livros e as livrarias, ou se é a mente das pessoas que participa desse ambiente, os editores, os leitores, os gerentes das livrarias etc. Nesta segunda hipótese, o ambiente dos memes será exclusivamente a mente e o resto será considerado parte do comportamento memeticamente determinado. Nas palavras de Dennett:

O estoque de mentes é limitado, e cada mente tem uma capacidade limitada de memes, portanto, há uma forte competição entre os memes para entrar no maior número de mentes possíveis. Esta competição é a principal força seletiva na memosfera. (DENNETT, 1991, p. 206).

Desse modo, temos que memes competem por espaço para replicação. Seria esta a principal força seletiva deles, que naquele esboço abstrato do darwinismo universal estaria no lugar do "recurso para reprodução" pelo qual os memes competem. Há um número muito maior de ideias, conceitos e comportamentos do que uma mente é capaz de aprender e, principalmente, executar. Esta seria uma pressão seletiva "interna” que se adicionaria à pressão “externa”. Como os memes são variáveis, é provável que tal variação seja adaptativa, no sentido de que pode auxiliar ou atrapalhar nessa competição. Se auxiliar, será dito que tal meme foi selecionado, pois, como vimos, ser selecionado significa somente ter um maior número de cópias do que a média da população. Como tais memes podem sofrer novos processos de variação e como essa nova variação pode ser adaptativa ou não, teremos um acúmulo de variaçôes, ou seja, há evolução.

Observar a cultura através da visão dos memes normalmente causa desconforto, pois, nesse caso, são os memes que se replicam e não nós que os replicamos porque queremos. São as palavras que querem ser ditas e não nós que as queremos dizer. Pensemos no caso de cultos que fazem "lavagem cerebral" e chegam até a levar ao suicídio coletivo. Pensemos também no processo de criação artística, onde um personagem de um romance ou um quadro ou uma música parecem ter uma vida própria. A ideia mesma de propaganda, por exemplo, vem da ideia de que um comportamento pode se propagar de pessoa em pessoa. Estes são casos em que sentimos claramente que quem comanda são os memes, são eles é que querem ser passados. Esta é a origem da visão de um meme como um vírus que invade nossa mente. Mas Susan Balckmore e Dennett não concordam com essa visão. Notemos as palavras do filósofo: 
O porto seguro de que todos os memes dependem é a mente humana, mas ela mesma é um artefato criado quando os memes reestruturaram um cérebro humano para torná-lo um habitat melhor para os memes. [...]

Mas se é verdade que as mentes humanas são, em grau notável, as criações de memes, então não podemos sustentar a polaridade de visão que analisamos anteriormente; não pode ser 'memes versus nós', porque infestaçóes anteriores de memes já tiveram um papel importante determinando quem ou o que somos. A mente 'independente' que luta para se proteger de memes alienígenas e perigosos é um mito. (DENNETT, 1991, p. 207).

Blackmore, concordando com Dennett, ressalta que o "eu" é um meme, ou melhor, um conjunto de memes extremamente bem adaptados à nossa mente e com uma forte estratégia protetora, pela qual tudo que náo é ele é tido como perigoso (BLACKMORE, 1999, p. 231). O "eu" é um complexo de memes do mesmo modo como um organismo é um complexo de genes, cada um trabalhando em benefício próprio. Tal questão não será tratada aqui, mas já logo veremos que essa posição não é necessária para se compreender a memética, porque tanto há defensores da memética que negam a existência do sujeito quanto há defensores, como Kate Distin, que, em um livro recente sobre a memética, aborda o papel de um agente da mudança memética que seria o sujeito de tal mudança (cf. DISTIN, 2005, p. 172) ${ }^{5}$. No entanto, é possível compreender a memética de uma maneira que não precisa ver os memes nem como invasores que dominam a nossa mente para benefício próprio, mas também não precisa de um conceito forte de "sujeito de seleção dos memes".

Memes devem ser passados por imitaçáo, para isso têm que se adaptar ao aparato cognitivo dos seres vivos capazes de imitação. Pode ser verdade que tais seres vivos sejam sujeitos livres e capazes de escolha, contudo, isso não faz fundamentalmente diferença nenhuma. Tais seres, mais especificamente os seres humanos, sempre terão uma maior probabilidade de imitar algum comportamento do que outro 6 . O aparato cognitivo humano, seja ele capaz de escolha ou não, pode ser considerado só como parte do ambiente ao qual o meme deve se adaptar. Memes mais bem adaptados a tal ambiente se tornarão mais comuns.

\footnotetext{
${ }^{5} \mathrm{O}$ mesmo poderia ser dito de Rosaria Conte (CONTE, 2000, p. 90).

6 Experimentos da Psicologia evolutiva (MITHEN, 2002) e da Ecologia Comportamental (DUGATKIN, 2000) vêm revelando isso e, dessa forma, estudando o ambiente seletivo dos memes.
} 
Para um ser humano, seu aparato cognitivo pode ser o que o faz escolher entre o que imitar e o que não imitar, mas, para um meme, ele é só parte do ambiente ao qual ele deve se adaptar. Ao contrário do que muitas vezes fica subentendido na analogia do meme com um vírus que invade nossa mente, um meme não nos domina ignorando as nossas capacidades cognitivas: ele "nos domina" por causa de tais capacidades! Se não tivéssemos predileção por determinados memes, todos os memes teriam a mesma chance de se multiplicar. Não haveria seleção e, consequentemente, não haveria evolução.

\section{II}

Quando Dawkins criou o meme de meme, ele estava simplesmente querendo mostrar que o importante do gene não era ser uma molécula da DNA, mas ser um replicador. Tendo criado o conceito em 1976, por anos ele passou sendo pouco citado e, quando o faziam, era mais comum que fosse dentro de uma crítica. Todavia, em 1991, com o livro Consciousness Explained, o filósofo Daniel Dennett passa a adotar o conceito de meme na sua teoria da mente. Em 1995, com Darwin's Dangerous Idea, Dennett separa um capítulo inteiro do seu renomado livro para defender o conceito de memes e discutir a possibilidade de uma ciência dos memes, a memética. Desse modo, o meme do meme se mostrou muito bem adaptado à sua mente e encontrou lá o seu mais renomado defensor. Dawkins inclusive declarou que Dennett é o mentor filosófico dos memes (DAWKINS, in BLACKMORE, 1999, p. xvi).

Em seu livro Quebrando o Encanto (2006), Dennett continua a usar os memes, e todas as intuiçóes oriundas dessa análise da cultura, como central em sua teoria, mais especificamente, sobre o surgimento e a permanência das religióes, embora pareça mais cauteloso com os exageros cometidos por muitos críticos e entusiastas da memética. Ele enfatiza, inclusive, uma fórmula interessante para se julgar tal questão: quanto mais crítico, ou mais entusiasta, maior a probabilidade de estar "falando besteira" em relação ao tema (DENNETT, 2006, p. 93). O interessante é que normalmente tanto os críticos quanto os entusiastas erram por exagerar nas analogias com a genética, quer dizer, por levá-las longe demais. As analogias podem ser bastante úteis, mas, na maioria das vezes, têm somente um valor heurístico e não um valor científico, ou seja, elas nos ajudam a entender, mas não provam nem demonstram absolutamente nada. É preciso, antes de tudo, estudar a evolução 
cultural por ela mesma, com todas as suas idiossincrasias, as quais não têm análogos na evolução genética.

A capacidade de explicar a mudança cultural através de histórias que mostrem a adaptabilidade sequencial e gradativa de um de seus traços às estruturas cognitivas humanas é o que uma ciência dos memes deve fazer. Porém, a memética, mesmo antes de surgir, já se encontra sob forte escrutínio, que é descabido por várias razões diferentes. O primeiro e mais óbvio erro, no que diz respeito à compreensão da memética, é achar que ela constitui apenas uma nova roupagem para antigas tentativas de darwinizar a cultura.

A memética seria uma ciência capaz de aplicar a perspectiva do meme. Tal perspectiva é semelhante às narrativas históricas adaptacionistas comuns na biologia evolutiva. Ao estudar um meme, deve-se salientar o que o torna um bom replicador, ou seja, o que o faz adaptado a uma determinada mente. É nisso que a memética se diferencia de outras teorias, as quais normalmente sáo confundidas com ela, a saber, o Darwinismo Social, a Sociobiologia, a Psicologia Evolutiva, o chamado efeito Baldwin etc. No entanto, a única relação que a memética tem com essas teorias é o fato de que todas elas estáo incluídas dentro do panorama geral do darwinismo universal, que visa a aplicar a estrutura da seleção natural a outros campos fora da biologia ou à biologia de outros planetas. Não obstante, em muitos casos, a memética é até mesmo oposta a essas teorias! O fato é que o estudo dos memes não pode ser considerado mais uma versão do determinismo genético, muito pelo contrário: a memética é oposta ao determinismo genético, justamente por indicar que muitos comportamentos são passados por transmissão cultural e não pelos genes. A perspectiva do meme significa que são os memes, assim como os genes, que querem ${ }^{7}$ ser passados $-\mathrm{e}$ não as pessoas que os querem passar.

Como era de se esperar, a memética sofreu várias críticas que a impediram de se desenvolver, pois um estudioso dessa área tem sempre que responder a uma infinidade de questóes para justificar o seu trabalho, ao invés de fazer como um pesquisador comum e simplesmente trabalhar. Quase não há trabalho empírico que se autointitule memética e assim será enquanto os

7 É evidente que está sendo usado aqui o que Dennett chamaria de Postura Intencional: os memes e os genes não querem realmente nada, apenas se reproduzem com maior ou menor eficácia, mas podemos tratá-los como se quisessem. Durante todo este trabalho, essa "postura" será utilizada, pois ela é mais simples e mais intuitiva, mas a linguagem mentalista para tratar de genes e memes não deve ser tomada literalmente. 
defensores dessa área acreditarem que há muito trabalho conceitual a fazer ${ }^{8}$. Dentre as principais críticas à memética, podemos citar as que se seguem.

Entre as críticas específicas, uma das mais comuns é que não sabemos a natureza dos memes, significando que não sabemos ainda do que eles são feitos, qual é o seu substrato físico. Outra também bastante comum é que não sabemos qual é o critério de unidade dos memes. Seria, por exemplo, uma música só um meme ou um conjunto de memes? Outra crítica diretamente relacionada a esta é a que destaca que o meme se mistura com outros memes, de modo que isso o torna relevantemente diferente dos genes. Também temos o problema de se a memética é realmente darwinista ou é, na verdade, lamarckista. Uma das críticas mais importantes, e que causa boa parte da repulsa ao conceito de meme, é sobre o papel do sujeito livre na evolução cultural.

Além dessas críticas, existem problemas, levantados pelos próprios defensores da memética, ainda em busca de respostas. Há a discussão de se memes podem ser passados só por imitação ou também por outras formas de aprendizado social. Há o problema de a velocidade da mudança cultural ser exageradamente rápida, de sorte a comprometer a fidelidade da transmissão e, assim, impedir a evolução. Há o problema de como distinguir se traços culturais semelhantes são cópias um do outro ou desenvolvimentos independentes. Isso levou o próprio Dennett a desacreditar de uma ciência dos memes, mesmo que ainda defenda sua utilidade filosófica e explicativa.

Há ainda críticas mais gerais, como a da cientificidade de uma disciplina histórica da cultura. Pode a memética ser realmente uma ciência? Que tipo de ciência ela seria? A memética teria uma base empírica ou seria apenas uma análise conceitual? Além disso, há o problema da relaçáo da memética com as ciências humanas que sentiram sua área invadida. Qual seria a relação da memética com essas diversas áreas? Sem contar com o forte preconceito que

\footnotetext{
${ }^{8}$ Eventualmente, alguns autores fazem uma pequena referência relacionando seu trabalho com a memética, como Dugatkin fez isso com a Ecologia Comportamental (DUGATKIN, 2000) e Don Ross fez com a economia (ROSS, 2002). Todavia, talvez os mais interessantes sejam os trabalhos de coevolução entre gene e cultura, tanto propostos por Richerson e Boyd (RICHERSON; BOYD, 2005 e 2006) quanto por Cavalli-Sforza e Feldman (CAVALLI-SFORZA, 2003), os quais, embora não se autointitulem memética, às vezes são até críticos desta, mas mesmo assim podem ser compreendidos como relacionando a evolução memética à evolução genética, de maneira que foram assim considerados por alguns autores (LALAND; BROWN, 2002, p. 249; DAWKINS, 2007, p. 259; LALAND; ODLING-SMEE, 2000, p. 136).
} 
tais áreas, mais especificamente a antropologia, têm com qualquer tentativa darwinista de trabalhar a cultura?.

Malgrado Dennett tenha se mostrado um cético em relação à memética, suas discussôes deram início a várias outras consideraçôes sobre uma ciência dos memes. Se o meme do meme, criado por Dawkins, foi achar seu lugar na mente de Dennett, o meme da memética, propagado por Dennett, encontrou seu espaço na mente de Susan Blackmore, que foi considerada por Dawkins e Dennett como a principal defensora da memética. "Foi Susan Blackmore, em The Meme Machine, que levou a teoria memética mais longe" (DAWKINS, 2007, p. 259). Foi nesse livro de 1999 que ela fez o que é ainda tido como um dos melhores modelos de como a memética deveria ser, embora vejamos que não é nem de longe uma ciência bem desenvolvida.

Para entender as análises de Blackmore, é importante ressaltar que há na memética uma mudança de ponto de vista extremamente necessária para compreender o que ela traz de novo ao estudo da cultura e à compreensão do que é ser um ser humano. $\mathrm{O}$ sucesso de um meme não se dá a despeito dos seres humanos, mas por causa deles. Do ponto de vista dos memes, os seres humanos são o ambiente ao qual eles devem se adaptar. Nasce, assim, a chamada perspectiva-dos-memes. A memética trata a cultura náo do ponto de vista dos humanos, mas do ponto de vista da própria cultura. Em última instância, é isso o que significa tratar a cultura como uma replicadora por conta própria. É esse ponto de vista do meme como sujeito que a memética nos traz, e é esta sua grande inovação. Nas palavras de Blackmore:

Ao invés de pensar em nossas idéias como nossas próprias criaçóes, e como coisas que trabalham para nós, temos que pensar nelas como memes autônomos egoístas, que trabalham apenas no sentido de serem copiados (BLACKMORE, 1999, p. 8, tradução minha).

Não será possível aqui examinar os vários exemplos de Blackmore. Uma análise detalhada seria demasiadamente longa. Escolhemos um só exemplo, por considerar que ele melhor especifica o problema que estamos querendo levantar. Todavia, o que será explicitado aqui sobre ele pode ser estendido para todos os outros exemplos que ela dá, bem como para os exemplos propostos por Dennett e Dawkins. O ponto inicial para criar uma explicação memética é o seguinte:

\footnotetext{
${ }^{9}$ Todas essas críticas foram tratadas longamente na minha Tese de Doutorado, defendida na PUC-Rio, de onde este próprio texto se originou (LEAL-TOLEDO, 2009).
} 
Imagine um mundo cheio de hospedeiros de memes (ou seja, cérebros), e muito mais memes do que possivelmente poderiam vir a encontrar um lar. Agora se pergunte: quais sáo os memes que têm maior chance de encontrar um lar seguro, e serem passados adiante? (BLACKMORE, 1999, p. 37, tradução minha).

A ideia inicial está correta; o problema de Blackmore, assim como foi o caso de Dawkins e Dennett, é que ela só constrói just so stories, isto é, narrativas históricas interessantes e inteligentes, mas sem nenhum fundamento empírico mais preciso. Exatamente o que Gould temia (GOULD, 1992). Este, inclusive, faz várias críticas à memética, mas não as desenvolve (GOULD, 2003, p. 319). Por mais inteligentes e sagazes que sejam essas narrativas, isso não basta para fazer uma ciência: é preciso fundamento empírico.

O exemplo clássico, e um dos primeiros exemplos dados sobre memes, é o do celibato. Nesse caso, dizemos que uma pessoa celibatária náo tem filhos e, desse modo, não precisa gastar seu tempo com a criação deles. Assim, ela pode usar seu tempo para espalhar seus memes, dentre eles o meme do celibato. $\mathrm{O}$ mesmo poderíamos afirmar quanto aos memes do controle de natalidade. Nas palavras de Blackmore:

As mulheres que têm apenas um ou dois filhos, ou nenhum, são muito mais capazes de encontrar empregos fora de casa, ou de terem uma vida social excitante, ou de usar e-mail, escrever livros ou artigos, ou se tornarem personalidade políticas ou públicas, ou praticarem atividades que possam espalhar seus memes, inclusive os memes para o controle de natalidade e os prazeres de uma pequena família. São essas as mulheres que aparecem na mídia, cujos sucessos inspiram as outras pessoas, e que oferecem modelos de comportamento a serem copiados por outras mulheres (BLACKMORE, 1999, p. 140, tradução minha).

Podemos ver que há um certo estranhamento, quando se vê a cultura do ponto de vista dos memes, mas, se conseguirmos deixar nossas sensaçóes iniciais de lado, poderemos perceber que de fato mulheres com menos filhos têm muito mais tempo para espalharem os seus memes, inclusive os memes de ter menos filhos. Nesse sentido, tais memes têm uma vantagem adaptativa sobre os memes de ter mais filhos. Sabemos que, salvo raras exceçóes, nossa sociedade privilegia mulheres com poucos filhos. No entanto, Blackmore falha em mostrar por que essa alternativa é melhor do que outras que explicam o mesmo comportamento. A ideia pode ser interessante, porém, não há 
fundamentação empírica nenhuma. Pode ser, por exemplo, que existam estruturas no cérebro humano que incentivem a procriação e que, nesse caso, deveriam ser levadas em conta nessa narrativa adaptacionista do meme do controle de natalidade.

Assim como Gould percebeu corretamente que o darwinismo pode cair em um adaptacionismo exagerado, criando narrativas históricas inteligentes sem fundamento empírico nenhum, podemos detectar esse mesmo problema na memética. Existe um aparato conceitual, mas ainda lhe falta desenvolver praticamente todo o seu fundamento empírico. Isso não significa que as análises feitas por Blackmore estão erradas, somente que elas não são o suficiente, não são científicas, isso ainda não é a memética ${ }^{10}$. São necessários estudos mais detalhados da cultura, os quais sejam melhores que as explicaçóes concorrentes, fundamentar suas bases em conhecimentos sobre a psicologia e o cérebro humano, descobrir como memes passam, como são guardados e, principalmente, o que faz uma pessoa ser "invadida" por um meme e não pelo outro ${ }^{11}$.

\section{III}

Uma análise apressada da memética a considera como uma ciência ainda totalmente por fazer; entretanto, uma análise memética das ciências humanas pode revelar que isso não é necessariamente verdade. O objeto de estudo da memética, a cultura em todas as suas facetas, já vem sendo objeto de estudo de outras áreas há séculos. A memética propóe uma nova forma de abordar tal objeto, no entanto, isso não significa ignorar o que já foi feito no passado. Um olhar mais cauteloso é capaz de observar que muitas outras áreas desenvolveram estudos os quais podem interessar à memética e alguns que podem, até mesmo, ser reclassificados como estudos propriamente meméticos. Se os defensores da memética se detiverem nessas análises antes mesmo de tentar desenvolver novas abordagens, descobrirão que a memética é, de certa maneira, uma ciência que já existe.

\footnotetext{
${ }^{10}$ Como muito bem ressaltou O. Chateaubriand, em uma conversa pessoal durante a orientação da minha Tese de Doutorado, “[...] a memética ou é uma ciência ou não é nada!". Se ela não tiver uma fundamentaçáo empírica, uma estrutura matemática, capacidade experimental e preditiva, ela simplesmente não interessa. A memética não surgiu para ser só mais uma teoria interpretativa da cultura. ${ }^{11}$ É nesse sentido que a memética tem muito a ganhar com os estudos da psicologia e dos neurôniosespelho.
} 
Como enfatiza Dobhzansky, ao afirmar que "[...] nada na biologia faz sentido a não ser à luz da evolução”, o que Darwin fez foi em grande parte juntar as diferentes áreas da biologia dentro de uma compreensão unificada. Mais do que uma simples teoria, a evolução por seleção natural seria um tipo de "cola conceitual" capaz de unir diversas áreas. Embora estas fossem obviamente relacionadas, pois todas tratavam do mundo vivo de um modo ou de outro, não eram consideradas todas como fazendo parte de um mesmo arcabouço teórico, e lhes faltava até mesmo os conceitos necessários para um diálogo entre elas. Darwin demonstrou que, no fundo, todas eram faces diferentes de um mesmo problema. Com isso, ele foi capaz de unir a biologia em um todo coeso e conceitualmente coerente.

Um dos grandes benefícios da memética é justamente o fato de que ela talvez possa fazer o mesmo para as diversas abordagens da cultura que hoje se encontram separadas, sendo consideradas ciências distintas. Antropologia, linguística, sociologia, história, economia, marketing, design, pedagogia, publicidade e propaganda são só alguns exemplos de áreas que vêm, em alguns casos, há séculos trabalhando o desenvolvimento e a transmissão da cultura e devem todas ser respeitadas em sua individualidade, mas que podem ser compreendidas dentro de um mesmo conjunto conceitual originário da memética. Esta deve encontrar a unidade dentro da multiplicidade, evidenciando, por exemplo, que dentro do aparato conceitual memético aquilo que um publicitário faz está diretamente relacionado ao que um antropólogo e um economista fazem. É justamente essa habilidade da memética de unir áreas díspares a sua maior força e um dos principais motivos pelos quais devemos tentar desenvolver tal ciência.

Muitos exemplos poderiam ser dados, nas mais diversas áreas do saber humano, de como a memética pode usar as pesquisas já existentes não só para descobrir seu fundamento empírico, como para desenvolver métodos de pesquisa da cultura. Entretanto, talvez a área que melhor exemplifique isso seja a linguística, mas propriamente a linguística diacrônica ou histórica. Ao estudar a história das línguas, essa disciplina foi ao encontro de resultados muito semelhantes ao que esperaríamos de uma memética bem desenvolvida. Aqui serão apresentados apenas alguns resultados, mas qualquer livro de linguística histórica é capaz de nos dar muitos outros.

A primeira constatação para entendermos a mudança linguística é exatamente a mesma constatação que Darwin fez sobre os seres vivos e que permitiu o surgimento do pensamento populacional, em oposição ao 
essencialismo, a saber, a constatação da variabilidade interna das línguas. A variabilidade externa é bastante óbvia - línguas diferentes são diferentes. Mas a variabilidade interna precisa de um cuidado maior para ser compreendida, pois, de outro modo, qualquer variação interna será tomada somente como um erro particular. $\mathrm{O}$ mesmo problema existia na biologia, quando a variabilidade dentro de uma espécie era só tida como um pequeno erro ou desvio sem importância, e apenas a variabilidade entre as espécies era relevante. Contudo, tanto para a evolução das espécies, quanto para a evolução das línguas, é justamente essa variabilidade interna que importa, sendo que a diferença entre as espécies, e entre as línguas, é na verdade o acúmulo dessas pequenas diferenças. Nas palavras de Faraco:

As pesquisas dialetológicas (que se iniciaram por volta do fim do século XIX) e a sociolingüística (que se estruturaram a partir da década de 1960) têm demonstrado que não existe língua homogênea: toda e qualquer língua é um conjunto heterogêneo de variedades. Nesse sentido, quando usamos rótulos como português, árabe, japonês, chinês, turco para designar realidades lingüísticas, não fazemos referência a uma realidade homogênea ou a um padrão único de língua, mas sempre a um conjunto de variedades, podendo algumas ser até ininteligíveis entre si, como, por exemplo, o chinês pequinês e o chinês cantonês; ou o italiano da Calábria (sul da península itálica) e o italiano de Bérgamo (norte). (FARACO, 2005, p. 31).

Uma língua, que foi chamada na citação anterior de rótulo, não é um agrupamento homogêneo, porém, constitui um conjunto heterogêneo ligado por uma semelhança estatística. As semelhanças e diferenças dentro de uma mesma língua podem variar constantemente, sendo possível que de uma língua surjam várias outras, mas também sendo possível que diferenças sejam amenizadas, como vemos que está acontecendo neste exato momento, com a reforma ortográfica do português. Normalmente, as diferenças aumentarão ou diminuirão, dependendo da frequência do contato entre as diversas formas de uma língua. Exatamente como acontece entre as subespécies, ou espécies geográficas de uma espécie, as quais podem diminuir suas diferenças por intercruzamentos.

Outra forte semelhança entre as línguas e o reino natural é que tais diferenças se dão de uma maneira gradual. Não há um limite geográfico claro, com que possamos separar dois dialetos da mesma língua. Um estudo que demonstrou isso foi feito por Georg Wenker, em 1876. Ele enviou uma lista 
de sentenças em alemão padrão para vários professores de várias localidades da Alemanha, pedindo para que fosse colocada dentro do dialeto local.

Colocaram-se as respostas em mapas, buscando-se demarcar a fronteira entre o alto e o baixo alemáo. $\mathrm{O}$ resultado, porém, foi diferente do esperado: constatou-se que não havia uma fronteira nítida entre os dois grupos dialetais, mas áreas de transição em que o consonantismo do alto alemáo afetava apenas segmentos do léxico, isto é, no mesmo dialeto algumas palavras seguiam o padráo conservador do Norte, e outras, o padrão inovador do Sul. (FARACO, 2005, p. 188).

Vemos, portanto, uma outra característica da mudança linguística: ela não se dá aos saltos. A transição entre dois dialetos se dá por partes e aos poucos, e não de forma abrupta e radical. Tal fato garante, em um primeiro momento, a inteligibilidade dos dialetos, que pode, com o tempo, ou diminuir até que eles sejam tấo ininteligíveis um para outro que sejam considerados línguas distintas, ou também aumentar, reunindo os dois dialetos, ou simplesmente permanecer como estão. Pode acontecer ainda, obviamente, que um dialeto domine o outro de modo a suplantá-lo a ponto de o outro dialeto desaparecer. Mas o mais interessante no momento é que as mudanças linguísticas se dão de maneira lenta e gradual, passando por uma série de fases intermediárias, processo em tudo semelhante ao processo evolutivo na biologia:

O que é perceptível por esses estudos é que, em geral, determinada mutação avança por pequenos incrementos e por meio da seleção gradual entre membros de um conjunto de variantes coexistentes, processo que costuma durar relativamente longos períodos de tempo. (LABOV, 1972; LABOV; YAEGER; STEINER, 1972, LASS, 1978, entre outros, in: FARACO, 2005, p. 88).

Tal citação poderia muito bem estar em qualquer livro sobre evolução das espécies, sem a necessidade de qualquer modificação. Assim, temos dentro da linguística a própria base do pensamento populacional que, por sua vez, é a própria base da teoria da evolução por seleção natural: o lento e contínuo processo de mudança que transforma variaçóes internas em espécies (tipos):

$\mathrm{O}$ que era nesse longínquo ponto do tempo apenas um conjunto de variedades dialetais é hoje um emaranhado universo de línguas raramente compreensíveis entre si, resultado de milênios e milênios de ininterruptas mudanças e de contínua diferenciação. (FARACO, 2005, p. 46). 
Curiosamente, podemos ver que no lugar onde estaria, segundo o conceito biológico de espécie, a capacidade de intercruzamento como o critério separador das espécies, está a mútua compreensão entre as diversas línguas. A falta da mútua compreensão é justamente o que impede uma língua de se unir a outra e, desse modo, é o que as mantém distintas. Seria na biologia o chamado "mecanismo de isolamento". Nas palavras de Cavalli-Sforza:

Vale a pena notar que a unidade biológica espécie corresponde à unidade linguagem: ambas são grupos de indivíduos capazes de comunicar-se, isto é, de trocar informação. Membros de uma mesma espécie podem cruzar entre si e, assim, trocar informação genética, bem como indivíduos que falam a mesma língua comunicam-se trocando informação verbal. (CAVALLI-SFORZA; CAVALLI-SFORZA, 2002, p. 235).

Com esse exemplo, notamos que, ao tratar da cultura, a memética transita por áreas que abordam esse mesmo objeto há séculos. Poderiam ser levadas em consideração igualmente várias outras áreas que não serão tratadas aqui, como a economia, a antropologia, a história, a sociologia, a publicidade e propaganda etc. Dessas, a publicidade e propaganda mereceriam um destaque, pois são as áreas que não só estudam a transmissão de informação por diversos meios, como também são capazes de fazer algumas previsóes e até mesmo testá-las.

Uma propaganda qualquer, como as que estão presentes na televisão ou revistas, normalmente tem atrás de si todo um aparato teórico-conceitual que indica como levar o consumidor a comprar tal produto e que pode ser testada simplesmente vendo se tal propaganda teve o efeito desejado. A memética já poderia encontrar aí uma primeira base empírica de suas previsóes com a qual trabalhar.

Publicitários precisam saber como vender e, para isso, precisam entender como afetar o comportamento de alguém de maneira direcionada e previsível. Muito do que eles fazem é justamente baseado no tipo de pesquisa que interessa à memética (cf. NORMAN, 2004). Experimentos, que no futuro poderão ser considerados experimentos em memética, já foram realizados dentro da psicologia e são empregados por publicitários, enquanto outros surgem a todo o momento (DUGATKIN, 2000, p. 187).

Se as pesquisas e "experimentos" em publicidade e propaganda podem nos assegurar qual produto irá vender, ou qual música será escutada, pode ser também que nos garantam, por exemplo, qual variante linguística terá maior 
sucesso, ou qual novo hábito se propagará com mais rapidez, ou qual método pedagógico é mais eficaz. Dentro de uma perspectiva memética, publicidade, linguística, antropologia, sociologia, história etc. estão todas falando a mesma língua e devem trabalhar juntas, para estudar a cultura. As técnicas utilizadas nessas áreas poderiam ser reaproveitadas pela memética.

Se a memética for percebida dessa forma, ficará claro que ela não é uma ciência por fazer. Seu valor está antes de tudo na sua capacidade de unir diversas áreas que não se encontram no momento dentro de uma estrutura conceitual comum. Há, de fato, um longo caminho que ela deve percorrer, porém, já há um caminho percorrido por outras ciências correlatas e não é preciso percorrê-lo de novo. Podemos, em decorrência, ver a memética não só como uma promessa, mas como uma realidade em construção. A memética precisa, antes de tudo, de alguém com a capacidade de unir diversas pesquisas empíricas, realizadas pelas mais diversas áreas que estudam a cultura. Só assim ela terá embasamento empírico suficiente para se estabelecer como ciência.

Costuma-se perguntar se a memética está esperando pelo seu Michelson e Morley, que refutaram a doutrina do éter, ou pelo seu Watson e Crick, que descobriram a estrutura física dos genes. Todavia, se o que foi exposto aqui está certo, nenhuma das duas análises está correta. A memética ainda espera por seu Darwin: alguém com amplo conhecimento nas diversas áreas científicas que trabalham com a cultura e que seja capaz de mostrar como essas diversas áreas, no fundo, contam a mesma história e só podem ser compreendidas juntas. Nesse sentido, o grande erro dos defensores da memética até o momento foi o de ignorar tais pesquisas.

Isso não significa que a memética esteja certa, que ela é uma ciência e basta começar a fazer e não teremos problema algum. Este não é o ponto. A questão é que, para descobrir se a memética será uma ciência ou não, é preciso antes de tudo tentar! "A memética deveria ser avaliada apenas quando um número razoável de pessoas começasse a desenvolvê-la” (HULL, 2000, p. 51, tradução minha). Talvez no futuro ela encontre uma barreira intransponível e fracasse. Talvez memes sejam amorfos, misturando-se de todos os modos, sem unidade alguma, sem fidelidade alguma, instanciados das mais diferentes formas e não transmitidos entre cérebros. Talvez. Mas ela deve ser tratada como inocente, até que a provem culpada.

Ecologia comportamental, teorias da coevolução genecultura, linguística, antropologia, sociologia, história, economia, neurociências, 
design, modelos dinâmicos de epidemiologia, pedagogia, publicidade e propaganda, psicologia etc. Tudo isso deverá ser estudado pela memética. Há, com certeza, muito trabalho a ser feito. Trabalho em tudo semelhante ao que Darwin fez, na Origem das Espécies, quando juntou evidências de várias áreas distintas da biologia e demonstrou como elas, juntas, contavam exatamente a mesma história: a teoria da evolução por seleção natural. A união da biologia foi o grande feito de Darwin. "Sem a evolução a biologia se resume a uma miscelânea de fatos heterogêneos" (DAWKINS, 2005, p. 109). Mas uma "miscelânea de fatos heterogêneos" é exatamente o que temos nas ciências sociais, e é exatamente a união dos estudos sobre a cultura que poderá ser o grande feito da memética.

LEAL-TOLEDO, Gustavo. Searching for a foundations of memetics. Trans/Form/Ação, Marília, v. 36, n. 1, p. 187-210, Jan./Abril, 2013.

\begin{abstract}
The concept of memes was created by Richard Dawkins in 1976 as a cultural analogue of genes. It suggests the possibility of studying culture through a process of evolution through natural selection of memes, that is, of behaviors, ideas and concepts. The concept became central for the philosopher Daniel Dennett, who employed it in his theory of consciousness and made the possibility of a science of memes, called "memetics", known to the general public. Susan Blackmore (1999) comes closest to giving a complete defense of such a theory. However, memetics has been the target of heavy criticism, and has still not established itself as a science, with specific methods and a well-defined empirical basis.
\end{abstract}

KEYWORDS: Memes. Memetics. Universal Darwinism. Richard Dawkins. Daniel Dennett.

\title{
REFERÊNCIAS
}

BLACKMORE, S. The Meme Machine. Oxford: Oxford University Press, 1999.

CAVALLI-SFORZA, L.L. Genes, Povos e Linguas. São Paulo: Companhia das Letras, 2003. ; CAVALLI-SFORZA, F. Quem Somos? História da diversidade humana. São Paulo: UNESP, 2002.

DARWIN, C. A Origem das Espécies. Rio de Janeiro: Ediouro, 2004.

DAWKINS, R. O Gene Egoista. Belo Horizonte: Itatiaia, 2001.

. O Rio que Saía do Éden. Rio de Janeiro: Rocco, 1996. 
. O Capelão do Diabo. São Paulo: Companhia das Letras, 2005.

. Deus, um delírio. São Paulo: Companhia das Letras, 2007.

DENNETT, D.C. Consciousness Explained. Boston: Little, Brown and Company, 1991. . A Perigosa Idéia de Darwin. Rio de Janeiro: Rocco, 1998.

2006. . Quebrando o Encanto: a religião como um fenômeno natural. São Paulo: Globo,

DISTIN, K. The Selfish Meme. Cambridge: Cambridge University Press, 2005.

DUGATKIN, L.A. The Imitation Factor. Evolution Beyond The Gene. New York: The Free Press, 2000.

FARACO, C.A. Lingüistica Histórica. São Paulo: Parábola, 2005.

GOULD, S.J. A Montanha de Moluscos de Leonardo da Vinci. Sáo Paulo: Companhia das Letras, 2003.

. Dinossauro no Palheiro. São Paulo: Companhia das Letras, 1997.

. A Galinha e Seus Dentes. Rio de Janeiro: Paz e Terra, 1992.

HULL, D. Taking memetics seriously: Memetics will be what we make it. In: AUNGER, R. Darwinizing Culture. The Status of Memetics as a Science. Oxford: Oxford University Press, 2000, p. 43-69

LALAND, K.N.; BROWN, G.R. Sense \& Nonsense, evolutionary perspectives on human behaviour. Oxford: Oxford University Press, 2004.

LEAL-TOLEDO, G. Controvérsias Meméticas: a ciência dos memes e o darwinismo universal em Dennett, Dawkins e Blackmore. 2009. Tese (Doutorado em Filosofia) Departamento de Filosofia, Pontifícia Universidade Católica do Rio de Janeiro, Rio de Janeiro, 2009.

Dawkins, Dennett e as tentativas de universalização do darwinismo. Revista Brasileira de História da Ciência. Rio de Janeiro, V.1, n.1, p.253-258, 2009.

MAYR, E. Biologia, Ciência Única. São Paulo: Companhia das Letras, 2005.

Uma Ampla Discussão. Charles Darwin e a gênese do moderno pensamento evolucionista. São Paulo: Ed. FUNPEC, 2006.

MAYNARD-SMITH, J. The Theory of Evolution. Cambridge: Cambridge University Press, 1993.

MITHEN, S. A Pré-história da mente: em busca das origens da arte, da religião e da ciência. São Paulo: Ed. UNESP, 2002.

MONOD, J. O Acaso e a Necessidade. Rio de Janeiro: Vozes, 2006. 
NORMAN, D.A. Emotional Design: why we love (or hate) everyday things. New York: Basic Books, 2004.

RICHERSON, P. J.; BOYD, R. Not by genes alone: how culture transformed human evolution. Chicago: University of Chicago Press, 2006.

. The Origin and Evolution of Cultures. Oxford: Oxford University Press, 2005.

RIDLEY, M. Evolução. Porto Alegre: Artmed, 2006.

ROSS, D. Dennettian Behavioural Explanations and the Roles of the Social Sciences. In: BROOK, A.; ROSS, D. Daniel Dennett. Cambridge: Cambridge University Press, 2002, p. $140-186$.

RIZZOLATTI, G.; SINIGAGLIA, C., Mirrors in the Brain: how our minds share actions and emotions. Oxford: Oxford University Press, 2008.

STERELNY, K.; GRIFFITHS, P.E. Sex and Death: an introduction to Philosophy of Biology. Chicago: The University of Chicago Press, 1999. 
LEAL-TOLEDO, G. 